\title{
Common Tables and Democratic Solidarity
}

\author{
Patrizia Longo ${ }^{1}$
}

My central argument is that food is integral to political democratic practices. A defense of local and farmers' markets against global markets, prevalent in much of the literature on the democratization of food, seems inadequate because it does not necessarily undermine class inequalities that are incompatible with democratic citizenship. By exploring the Greek notion of common tables in the writings of Aristotle and Aristotle's and Marx's distinction between use and exchange value, I intend to show that shared meals based on common use instead of exchange and private markets can counter a range of inequalities that ordinarily undermine the practice of democratic citizenship. I will look at the Transition Towns Movement, at a small sustainable farm in Mount Shasta, California and at Slow Food's Terra Madre movement as instances of the democratizing potential of sharing food at "common tables" in both a real and metaphorical sense. [Article copies available for a fee from The Transformative Studies Institute. E-mail address: journal@transformativestudies.org Website: http://www.transformativestudies.org (C2013 by The Transformative Studies Institute. All rights reserved.]

KEYWORDS: Democratization of Food, Solidarity, Common Tables, Use Value, Exchange Value, Transition Towns, The Hermitage, Terra Madre.

\footnotetext{
${ }^{1}$ Patrizia Longo, Ph.D., was born and raised in Italy where she studied languages (English, German and French) before coming to the United States. She received her Bachelor's degree in political science and history from the University of Pennsylvania and her Master's and Doctorate in political science from the University of California at Berkeley. She is full professor in the Department of Politics at Saint Mary's College in Moraga, where she teaches courses in political theory, food politics, gender and race politics. She is the author of a book on Rousseau, The Myth of Glaucus: Rousseau's Modern Quest for Authenticity, and several articles in scholarly journals. She has been the recipient of three grants from the National Endowment for the Humanities (NEH). Her present work focuses on food justice and food sovereignty. Address correspondence to: Patrizia Longo, Department of Politics, Saint Mary's College of California, Moraga, CA 94549; e-mail: plongo@stmarys-ca.edu.
} 